\title{
A mutagenesis-derived broad-spectrum disease resistance locus in wheat
}

\author{
Jackie Campbell $\cdot$ Hongtao Zhang $\cdot$ Michael J. Giroux $\cdot$ \\ Leila Feiz $\cdot$ Yue Jin $\cdot$ Meinan Wang $\cdot$ Xianming Chen · \\ Li Huang
}

Received: 15 December 2011 / Accepted: 29 February 2012 / Published online: 25 March 2012

(c) The Author(s) 2012. This article is published with open access at Springerlink.com

\begin{abstract}
Wheat leaf rust, stem rust, stripe rust, and powdery mildew caused by the fungal pathogens Puccinia triticina, $P$. graminis f. sp. tritici, $P$. striiformis f. sp. tritici, and Blumeria graminis f. sp. tritici, respectively, are destructive diseases of wheat worldwide. Breeding durable disease resistance cultivars rely largely on continually introgressing new resistance genes, especially the genes with different defense mechanisms, into adapted varieties. Here, we describe a new resistance gene obtained by mutagenesis. The mutant, MNR220 (mutagenesis-derived new resistance), enhances resistance to three rusts and powdery
\end{abstract}

Communicated by J. Snape.

J. Campbell and H. Zhang contributed equally to this work.

J. Campbell $\cdot$ H. Zhang $\cdot$ M. J. Giroux $\cdot$ L. Feiz $\cdot$ L. Huang $(\bowtie)$

Department of Plant Sciences and Plant Pathology,

Montana State University, Bozeman, MT 59717-3150, USA

e-mail: lhuang@montana.edu

Present Address:

L. Feiz

The Boyce Thompson Institute for Plant Research,

Ithaca, NY 14853-1801, USA

Y. Jin

Cereal Disease Laboratory,

United States Department of Agriculture-Agricultural Research

Service (USDA-ARS), St. Paul, MN 55108, USA

M. Wang $\cdot$ X. Chen

Department of Plant Pathology, Washington State University, Pullman, WA 99164-6430, USA

X. Chen

Wheat Genetics, Physiology, Quality, and Disease Research Unit, United States Department of Agriculture-Agricultural Research

Service (USDA-ARS), Pullman, WA 99164-6430, USA mildew, with the characteristics of delayed disease development at the seedling stage and completed resistance at the adult plant stage. Genetic analysis demonstrated that the resistance in MNR220 is conferred by a single semidominant gene mapped on the short arm of chromosome $2 \mathrm{~B}$. Gene expression profiling of several pathogenesis-related genes indicated that MNR220 has an elevated and rapid pathogen-induced response. In addition to its potential use in breeding for resistance to multiple diseases, high-resolution mapping and cloning of the disease resistance locus in MNR220 may lead to a better understanding of the regulation of defense responses in wheat.

\section{Introduction}

Bread wheat (Triticum aestivum L.) provides approximately $40 \%$ of the food and $25 \%$ of the calories consumed globally (Board 2010). Bread wheat is an allohexaploid $(2 n=6 x=42)$ consisting of three related genomes designated $\mathrm{A}, \mathrm{B}$, and $\mathrm{D}$ with an estimated genome size of $16,000 \mathrm{Mb}$ (Arumuganathan and Earle 1991). This complex species arose from two successive hybridization and speciation events involving domesticated and wild grasses (Dvořák et al. 1993; McFadden and Sears 1964; Sarkar and Stebbins 1956). The relatively recent speciation and domestication history of wheat led to limited genetic variation within the species.

Modern wheat improvement efforts are centered on yield and increased resistance to biotic stresses, especially fungal pathogens. Disease resistance can be accomplished either through passive or active host defense mechanisms. Passive defense involves physical or chemical barriers to infection such as the cuticle and phytoanticipins presented by the host without direct pathogen recognition. Phytoanticipins 
are constitutively expressed tissue-specific antimicrobial chemicals (Bouarab et al. 2002) such as defensins that are found in the wheat endosperms (Colilla et al. 1990). Active defense, such as the hypersensitive response (HR), involves physiological changes in the host induced by pathogen recognition. Active defense involves signaling pathways such as those mediated by jasmonic acid (JA) and salicylic acid (SA). The SA signaling pathway is mainly induced by biotrophic pathogens and is correlated with high expression of specific $P R$ genes (Glazebrook 2005).

The three wheat rusts are leaf rust caused by Puccinia triticina $(P t)$, stem rust caused by $P$. graminis f. sp. tritici (Pgt), and stripe rust caused by $P$. striiformis f. sp. tritici (Pst). Powdery mildew is caused by Blumeria graminis $\mathrm{f}$. sp. tritici $(B g t)$. Rusts and powdery mildew are biotrophs capable of causing large scale epidemics. Breeding resistance to these diseases is a major undertaking in wheat improvement worldwide. Types of rust and powdery mildew resistances are characterized as race specific or nonspecific based on the mode of action. Race-specific resistance involves a gene-for-gene interaction between the host and pathogen (Flor 1956). This interaction depends on host recognition of pathogen effectors, or avirulence factors. This type of resistance is often controlled by a single host resistance gene ( $R$-gene) that triggers programed cell death at the infection sites. Although race-specific resistance is often highly effective, it tends to be short-lived as host recognition is easily overcome by a change in or the deletion of the corresponding pathogen effector. Alternatively, race non-specific resistance is primarily conferred by multiple genes with intermediate or additive effects. As race nonspecific resistance is not dependent upon a single gene-specific interaction it tends to be more durable. This type of resistance does not rely upon HR and confers resistance through retardation of disease development by a longer latent period, lower infection frequency, and/or reduced sporulation (Rubiales and Niks 1995).

$R$-gene mediated resistance has been used by wheat improvement programs for decades to control wheat rust diseases. However, only relatively small set of effective, rust $R$ genes deployed among cultivated varieties place a high selective pressure on pathogen populations. The selective pressure can lead to emergence of pathogen variants that avoid recognition by deployed $R$ genes, and hence are capable of causing devastating disease epidemics. One of the most recent incidents occurred in 1999 when Pgt race TTKSK (or Ug99) was first identified in Uganda and subsequently caused stem rust epidemics in Kenya (Pretorius et al. 2000; Stokstad 2007; Wanyera et al. 2006). Hence, breeding for rust resistance involves the continual introgression of new resistance genes into adapted cultivars. Here, we describe a wheat mutant identified from an ethyl- methane sulfonate (EMS) mutagenized population created in the spring wheat cultivar Alpowa (PI 566596) that exhibits dominantly inherited resistance to the three rusts and powdery mildew.

\section{Materials and methods}

Materials

Plant materials Alpowa (PI 566596) and McNair 701 (CItr 15288) were obtained from the USDA National Plant Germplasm System (NPGS). Chinese Spring was provided by Dr. Luther Talbert at Montana State University. Avocet Susceptible (AvS) is an Australia spring wheat cultivar originally provided by Dr. Colin Wellings, Plant Breeding Institute, University of Sydney. Identification of MNR220 and development of the near isogenic lines (NILs) were outlined in Fig. 1. Resistant and susceptible NILs were developed after eight generations of selfing from one $M_{7}$ heterozygous line 220-5. MNR220 heterozygous lines were selected at each generation with IT 2 to PBJL and confirmed with progeny tests of 20 seedlings.

Leaf rust isolate PBJL was provided by Dr. Robert Bowden from USDA-ARS, Manhattan, KS. The other two leaf rust isolates SBDGD and BBBDD and one stripe rust isolate PST-139 were collected in Creston, MT. Stem rust isolates were from the collection of the Cereal Disease Laboratory (CDL), St. Paul, MN. Stripe rust isolates were from the USDA-ARS, Wheat Genetics, Quality, Physiology and Disease Research Unit, Pullman, WA.

\section{Methods}

EMS-induced mutagenesis

The mutagenized population screened here was created by EMS seed treatment of the soft, white, spring wheat cultivar Alpowa (Feiz et al. 2009).

\section{Plant growth}

Seeds were germinated in $164 \mathrm{~mL}$ cone-tainers (Stuewe \& Sons Inc., Tangent, OR) filled with 50:50 Mix with half of MSU Mix and half Sunshine Mix \#1 by volume. Seedlings were grown in the MSU Plant Growth Center (MSU-PGC) greenhouse with $22 / 14{ }^{\circ} \mathrm{C}$ day/night temperatures and a 16-h photoperiod. Plants were watered as needed and fertilized every other day with Peters General Purpose Plant Food (Scotts-Miracle-Gro Company, Marysville, $\mathrm{OH}$ ). 


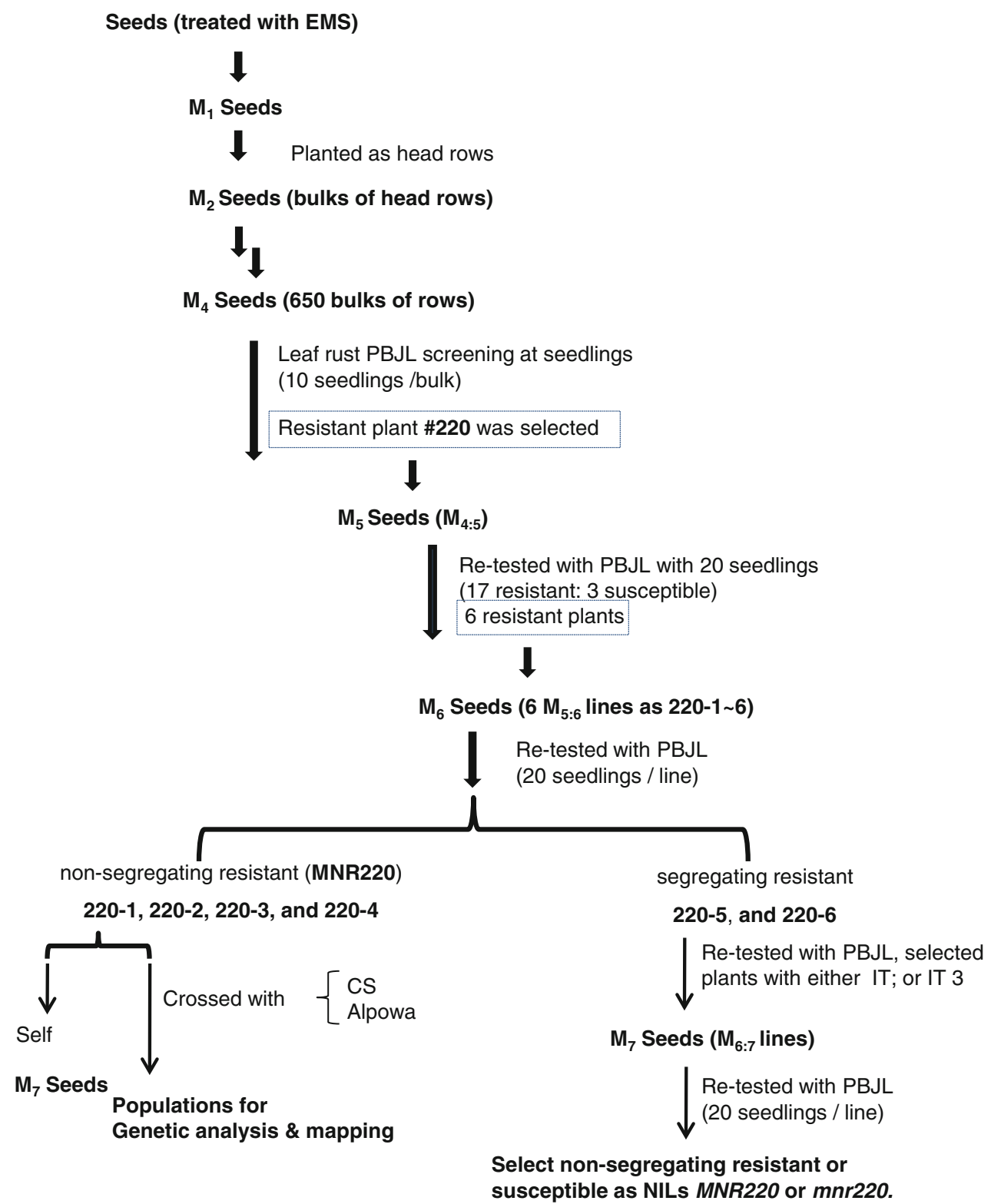

Fig. 1 A scheme showing steps of mutant identification, confirmation and genetic analysis. $\mathrm{M}_{n: n+1}$ line is used to describe $n_{+1}$ generation seeds that derived from one selected $n$ generation plant

Rust inoculation and disease assessment

\section{Leaf rust inoculation and disease assessment}

Leaf rust tests were conducted at MSU-PGC. Controlled greenhouse inoculations were performed on seedlings and adult plants. Each inoculation was conducted using race PBJL of $P$. triticina. The inoculum consisted of urediniospores suspended in Soltrol 170 Isoparaffin (Chempoint, Bellevue, WA). The spore inoculum density was calculated at 227,500 spores/ml using a Brightline hemocytometer as per the manufacturer's recommendations (Hausser Scientific, Horsham, PA). The inoculum was applied at a rate of
$0.05 \mathrm{mg}$ spores $/ 10 \mu \mathrm{l}$ Soltrol/plant using a Badger 350-3 airbrush gun (Badger Air-Brush Co., Franklin Park, IL). Spore germination rate was assessed on an inoculated microscope slide using a light microscope. Inoculated plants were immediately transferred to a Percival I-60D dew chamber (Percival Scientific Inc., Perry, IA) pre-conditioned to an air temperature of $15-17{ }^{\circ} \mathrm{C}$ and incubated for $24 \mathrm{~h}$. The plants were then transferred to the greenhouse bench and grown under the conditions described above. Disease responses were assessed when rust symptoms were fully expressed on Alpowa 8-22 dpi using the seedling 0-4 IT scale (McIntosh et al. 1995; Stakman et al. 1962). In details, IT 0: no visible uredia; IT;: hypersensitive flecks; 
IT 1: small uredia with necrosis; IT 2: small- to mediumsized uredia with green islands surrounded by necrosis; IT 3: medium-sized uredia without necrosis; IT 4: large-sized uredia without necrosis. The variations within each class are indicated by the use of - (less than average for the class) and + (more than average for the class). When variable reactions were observed, IT ranges are listed from lowest to highest.

\section{Stripe rust inoculations and disease assessments}

The stripe rust nursery at the Northwestern Agricultural Research Station, Creston, MT was used for adult plant stripe rust assessments. The materials were planted in triplicated three hill plots $2 \mathrm{~m}$ apart. Stripe rust was assessed at anthesis stage based on the disease severity scales described by McIntosh et al. (1995).

Additional stripe rust assessments were conducted under controlled greenhouse conditions in Pullman, WA. Races PST-78 and PST-127 were used separately in seedling and adult plant tests. About ten plants were used in each test. For the seedling tests, plants of Alpowa, MNR220 and AvS (used as a susceptible check) at the two-leaf stage were dust inoculated with a mixture of urediniospores and talc (Fisher, Pittsburgh, PA) in a ratio of $1: 20$ and incubated in a dew chamber at $10{ }^{\circ} \mathrm{C}$ without light for $24 \mathrm{~h}$. The inoculated seedlings were grown in a growth chamber with a diurnal temperature cycle gradually changing from $4{ }^{\circ} \mathrm{C}$ at $2: 00$ am to $20^{\circ} \mathrm{C}$ at $2: 00 \mathrm{pm}$ with a 16-h photoperiod in each cycle. For the adult plant tests, plants at booting were inoculated, incubated in a dew chamber, and grown in a growth chamber in the same way as for the seedling tests, except with a diurnal temperature cycle gradually changing from $10{ }^{\circ} \mathrm{C}$ at 2:00 am to $30{ }^{\circ} \mathrm{C}$ at $2: 00 \mathrm{pm}$. Stripe rust infection types were assessed based on a 0 (immune)-9 scale (highest susceptible) (Line and Qayoum 1992).

\section{Stem rust inoculation and disease assessment}

Stem rust assessments were conducted at both the MSUPGC and the University of Minnesota. Tests with QFCSC and TLMKC were conducted at MSU-PGC. Inoculations were conducted in a similar manner to leaf rust with the following exceptions: the dew chamber was pre-conditioned to an air temperature of $19-22{ }^{\circ} \mathrm{C}$ and incubated for $24 \mathrm{~h}$, followed by incubation under high humidity and light intensity conditions for at least $3 \mathrm{~h}$ before being transferred to the greenhouse. Assessments were made when Alpowa showed full susceptibility 10-28 dpi using a modified Stakman et al. (1962) 0-4 IT scale (McIntosh et al. 1995).

Stem rust tests with additional races including TTKSK (Ug99) and its variants were conducted at the USDA/
University of Minnesota St Paul, MN, Disease Laboratory. Inoculation procedures and disease assessment were as described (Jin et al. 2007).

Genetic analysis

For genetic analysis, homozygous mutant MNR220 (220-1) (Fig. 1) at $\mathrm{M}_{6}$ was crossed with Alpowa (as male parent) and Chinese Spring (as female parent). Ten $F_{1}$ individuals each from the two crosses were tested as resistant to PBJL and selfed to produce $\mathrm{F}_{2}$ seeds with the possibility of outcrossing being prevented by the bagging of heads prior to anthesis. The $281 \mathrm{~F}_{2}$ individuals used for segregation analysis were from a combination of three $F_{1: 2}$ populations between MNR220 and Alpowa, and all $136 \mathrm{~F}_{2}$ individuals between Chinese Spring and MNR220 were from one $F_{1: 2}$ population. $\mathrm{F}_{2}$ seedlings were inoculated with PBJL and ITs were assessed on a single plant at 8,10 and 12 dpi three time points during disease development.

In order to assess whether the same locus confers the resistance to leaf rust, stem rust and powdery mildew, we tested the three pathogens on each of the eight $\mathrm{F}_{2: 3}$ lines from MNR220/Alpowa and $98 \mathrm{~F}_{2: 3}$ lines from Chinese spring/MNR220 with three different sets of 20 seedlings each from the same $F_{2: 3}$ line. If all three sets of 20 seedlings were not segregating or all three were segregating to the $P t$, $P s t$ and $B g t$ races, we describe the resistance to the three pathogens was co-segregating in this $\mathrm{F}_{2: 3}$ line.

Genomic DNA isolation and marker analysis

A cross between Chinese Spring and MNR220 was used for genetic mapping of the MNR220 locus. Leaf tissues for genomic DNAs were collected from the parents and $F_{2}$ individual plants but genotypes of the $\mathrm{F}_{2}$ plants were based on the tests of 20 seedlings from each of the $\mathrm{F}_{2: 3}$ lines. Genomic DNAs were isolated using the QIAGEN DNeasy Plant Mini Kit (Qiagen Sciences Inc, Germantown, MD). For bulked segregant analysis (Michelmore et al. 1991), two resistant and two susceptible DNA bulks were assembled using equal amounts of DNA from 5 or 10 homozygous resistant and 5 or 10 homozygous susceptible $\mathrm{F}_{2}$ plants, respectively. Wheat simple sequence repeat (SSR) markers (Xgwm, Xwmc, Xbarc, Xcfa, Xcfd and Xcfp series) from 21 wheat chromosomes and some of the wheat ESTSTS markers located on chromosome 2BS were used for screening polymorphisms between the two parents. Sequences of the primers of these SSR and EST-STS markers are available from GrainGenes2.0 website http://wheat. pw.usda.gov and http://wheat.pw.usda.gov/SNP/primers/ contig_primer_list.xls. Then, the polymorphic markers between the parents were used to screen the resistant and susceptible bulks. The markers revealed the same polymorphic 
patterns between the parents and the resistant and susceptible bulks were tested in the entire population.

PCR amplifications were conducted in $20 \mu \mathrm{l}$ reactions containing $20 \mathrm{mM}$ Tris- $\mathrm{HCl}, \mathrm{pH} 8.3,100 \mathrm{mM} \mathrm{KCl}$, $3.0 \mathrm{mM} \mathrm{MgCl}_{2}, 0.4 \mathrm{mM} \mathrm{dNTP}, 50 \mathrm{ng}$ of each primer, $100 \mathrm{ng}$ genomic DNA and $1.5 \mathrm{U}$ Taq DNA polymerase. Amplifications were performed at $94{ }^{\circ} \mathrm{C}$ for $5 \mathrm{~min}$, followed by 40 cycles at $94{ }^{\circ} \mathrm{C}$ for $45 \mathrm{~s}, 50-60{ }^{\circ} \mathrm{C}$ (depending on specific primers) for $45 \mathrm{~s}$, and $72{ }^{\circ} \mathrm{C}$ for $30 \mathrm{~s}-1 \mathrm{~min}$ (depending on different primers), with a final extension at $72{ }^{\circ} \mathrm{C}$ for $10 \mathrm{~min}$. PCR products were mixed with $3 \mu \mathrm{l}$ loading buffer (98\% formamide, $10 \mathrm{mM}$ EDTA, $0.25 \%$ bromophenol blue, and $0.25 \%$ xylene cyanol) and separated in 8 or $12 \%$ non-denaturing polyacrylamide gels (39:1 acrylamide:bisacrylamide) (EMD Chemicals Inc, Gibbstown, NJ) and stained by GelRed (Bio-Rad, Hercules, CA).

\section{Data analysis and genetic mapping}

Chi-squared test $\left(\chi^{2}\right)$ was used to evaluate deviations of observed data from theoretically expected segregation ratios. Linkages between molecular markers and the resistance gene were determined using Mapmaker 3.0b (Lincoln et al. 1992) with an LOD score of 3.0 as the threshold. The genetic map was drawn with the software Mapdraw V2.1 (Liu and Meng 2003).

Transcript abundance analysis by RT-qPCR

In order to assess the transcript abundances of seven $P R$ genes, relative quantitative reverse transcriptase polymerase chain reaction (RT-qPCR) and gene-specific primers from Desmond et al. (2008), designed based on wheat sequences, were used. Inoculation with Soltrol 170 was used as mock control. Leaf tissues were collected at $0,0.5$, $1,1.5$ and 5.5 dpi with PBJL and stored at $-80{ }^{\circ} \mathrm{C}$ until RNA isolation. Total RNA was isolated and treated with DNase I on column using the Qiagen RNeasy Plant Mini Kit (Qiagen, Valencia, CA) as per the manufacturer's suggestions. The quality and concentration of total RNA were assessed via agarose gels and $260 / 280_{\mathrm{ABS}}$ measurements on a NanoDrop 1000 spectrophotometer (Thermo Fisher Scientific Inc., Wilmington, DE). To exclude contamination with genomic DNA (gDNA) each RNA sample was used as template in a reverse transcriptase-free PCR reaction using the Actin (ACT) control primers specific to wheat as per the manufacturer's protocol. The same volume and concentration of the normalized RNA was used as template in each reaction as normalized ACT transcript abundance using iScript One-Step RT-PCR Kit with SYBR Green (Bio-Rad, Herculeqs, CA) as per the manufacturer's recommended protocol. Transcript abundance was quantified via real time PCR on a CFX96 real time PCR detection system (Bio-
Rad, Hercules, CA) using the iScript One-Step RT-PCR Kit with SYBR Green (Bio-Rad, Hercules, CA) and gene-specific primers. Each reaction was conducted in triplicate of the two biological replicates and data were used only if the standard deviation between replicates was $\leq 0.3 C_{\mathrm{t}}$. The ACT gene-specific primers are ACT forward.

5'AAATCTGGCATCACACTTTCTAC3' and ACT reverse 5'GTCTCAAACATATCTGGGTCATC3', amplified a 127-bp product of the coding sequence of the gene. All $P R$ gene primer sets were based on Desmond et al. 2008. Transcript abundance was calculated with the threshold cycle $\left(C_{\mathrm{t}}\right)$ using the $\Delta \Delta C_{\mathrm{t}}$ method as described in the CFX96 manual (Bio-Rad, Hercules, CA), where fold change $=2-\Delta \Delta C_{\mathrm{t}}$ and percent transcript abundance $=$ fold change $\times 100$. The transcript abundances for each group were calculated as the average plus or minus the average difference between the average and the highest and lowest values in that group. All statistical analyses were conducted using Microsoft Excel (Microsoft Corp., Redmond, WA).

\section{Results}

Creation and identification of a new resistance gene

The EMS-mutagenized population used in this study (Feiz et al. 2009) was created using the soft white spring wheat cultivar Alpowa. Initial rust screening was done at the $\mathrm{M}_{4}$ generation (Fig. 1). In detail, approximately 10 seedlings from each of $650 \mathrm{M}_{4}$ families were inoculated with $P t$ race PBJL. Response to the pathogen was assessed 8 days postinoculation (dpi) and described as infection type (IT) on a 0 (immune) to 4 (susceptible) scale (McIntosh et al. 1995). From the $\sim 6,500$ individual plants tested, 11 individual plants from different $\mathrm{M}_{4}$ families were selected based on their enhanced resistance compared to wild-type Alpowa. The selected plants showed moderate resistance characterized by small pustules surrounded by necrosis with IT $22^{+}$ and were rated as resistant. Alpowa had medium-sized pustules without necrosis and was rated as susceptible with IT 3. The resistance of each of the four selected plants was confirmed by $\mathrm{M}_{4: 5}$ progeny tests using the same $P t$ race on $20 \mathrm{M}_{5}$ seedlings. Here, we focus on one mutant line selected from 10 seedlings of a single $\mathrm{M}_{4}$ family labeled as \#220 in the mutagenized Alpowa population of Feiz et al. (2009). The single plant was selfed at the $M_{4}$ generation and the $20 \mathrm{M}_{4: 5}$ seedlings were tested with PBJL, showing a segregation ratio of 17 resistant to 3 susceptible. Among the 20 seedlings, six resistant individuals labeled as $220-1$ to 6 with IT 1-2 were selfed. Twenty seedlings from each of the $\mathrm{M}_{5: 6}$ were tested with PBJL, four $\mathrm{M}_{5: 6}$ lines (220-1, 220-2, 220-3, 220-4) showed non-segregating resistance with IT; 1 on all 20 seedlings, indicating they were homozy- 
gous for PBJL resistance (Fig. 1). Hereafter, we designate the homozygous resistant plants derived from the \#220-1 as mutant MNR220 (Mutagenesis-derived New Resistance) and the mutated allele as MNR220.

In addition to leaf rust tests, different seedlings of 220-1 $\mathrm{M}_{5: 6}$ line were tested with $13 P g t$ races representing diverse virulence combinations, including races in the Ug99 lineage (Jin et al. 2008, 2009). At the seedling stage, Alpowa and MNR220 showed similar ITs to RCRSC (IT 2-), RKQQC $\left(\mathrm{IT} ; 1^{+}\right.$), and QCCSM (IT 22 ${ }^{+}$) (Table 1), suggesting that Alpowa was resistant to these three races. MNR220 showed moderately lower ITs to TRTTF (IT 12) and MCCFC (IT; 1$)$ compared to Alpowa, suggesting the mutant has enhanced resistance to these two races (Table 1). Alpowa exhibited ITs 34 to TLMKC, QFCSC, TPMKC, TTKSK, TTKST, and TTTSK, whereas MNR220 had distinctly low ITs $; 1^{+}$to these races.

MNR220 was also tested with two Pst races at the seedling and one Pst race at the adult plant stages. At the seedling stage, MNR220 and Alpowa showed similar susceptible ITs to Pst races PST-78 (IT 7 and 8) and PST-127 (IT 8) (Table 1). Additionally, at the adult plant stage, MNR220 and Alpowa showed similar resistant ITs 2 to PST-127 (Table 1).

The $\mathrm{M}_{6}$ generation of MNR220 and Alpowa was planted at one field location in Creston, Montana in 2010 with three replications (3 hill plots/replication) for disease assess-

Table 1 Infection types (IT) of MNR220, Alpowa and McNair 701 challenged with races of Puccinia tritici (Pt), P. striiformis f. sp. tritici (Pst), and $P$. graminis f. sp. tritici $(P g t)$

\begin{tabular}{|c|c|c|c|c|c|}
\hline \multirow[t]{2}{*}{ Pathogen } & \multirow[t]{2}{*}{$\operatorname{Race}^{\mathrm{b}}$} & \multirow[t]{2}{*}{ Growth stage } & \multicolumn{3}{|c|}{ Infection type ${ }^{a}$} \\
\hline & & & Alpowa & MNR220 & McNair 701 \\
\hline \multirow[t]{4}{*}{$P t$} & \multirow[t]{2}{*}{ PBJL } & Seedling $^{\mathrm{c}}$ & $3^{+} 4$ & ;2 & $3^{+}$ \\
\hline & & Adult $^{\mathrm{c}}$ & $\mathrm{S}$ & $\mathrm{R}$ & $\mathrm{S}$ \\
\hline & SBDGD & Adult $^{\mathrm{d}}$ & $S$ & I & \\
\hline & BBBDD & Adult $^{\mathrm{d}}$ & $S$ & I & \\
\hline \multirow[t]{4}{*}{ Pst } & PST-78 & Seedling ${ }^{\mathrm{e}}$ & 8 & 7 & \\
\hline & PST-127 & Seedling ${ }^{\mathrm{e}}$ & 8 & 8 & \\
\hline & PST-127 & Adult $^{\mathrm{e}}$ & 2 & 2 & \\
\hline & PST-127, PST-139 & Adult $^{\mathrm{d}}$ & $S$ & $\mathrm{R}$ & \\
\hline \multirow[t]{13}{*}{$P g t$} & TLMKC & Seedling $^{c}$ & $3^{-4}$ & $; 1^{+}$ & $3^{+} 4$ \\
\hline & QFCSC & Seedling $^{c}$ & 34 & $; 1^{+}$ & $3^{+} 4$ \\
\hline & TTKSK & Seedling ${ }^{\mathrm{f}}$ & $3^{-} 3^{+}$ & ; & 4 \\
\hline & TTKST & Seedling ${ }^{\mathrm{f}}$ & $3^{+}$ & $; 1^{+}$ & 4 \\
\hline & TTTSK & Seedling $^{\mathrm{f}}$ & $3^{+}$ & ; & 4 \\
\hline & TRTTF & Seedling ${ }^{\mathrm{f}}$ & $22^{+}$ & 12 & $2^{+} 3^{-}$ \\
\hline & QTHJC & Seedling ${ }^{\mathrm{f}}$ & $3^{+}$ & 3 & 4 \\
\hline & MCCFC & Seedling ${ }^{\mathrm{f}}$ & $; 2$ & $; 1$ & 4 \\
\hline & RCRSC & Seedling ${ }^{\mathrm{f}}$ & $2^{-}$ & $2^{-}$ & 4 \\
\hline & RKQQC & Seedling ${ }^{\mathrm{f}}$ & $; 1^{+}$ & ; & 4 \\
\hline & TPMKC & Seedling ${ }^{\mathrm{f}}$ & 4 & ; & 4 \\
\hline & TTTTF & Seedling ${ }^{\mathrm{f}}$ & 4 & $3^{+}$ & 4 \\
\hline & QCCSM & Seedling ${ }^{\mathrm{f}}$ & $2^{+}$ & 2 & 4 \\
\hline
\end{tabular}

\footnotetext{
${ }^{a}$ Infection types indicated as per 0 (immune)-4 (susceptible) scale was used for $P t$ and per 0 (immune)-9 (susceptible) scale for $P s t$ as described in McIntosh et al. (1995). $O$ no visible uredia,; hypersensitive flecks, 1 small uredia with necrosis, 2 small- to medium-sized uredia with green islands and surrounded by necrosis, 3 medium-sized uredia without necrosis, 4 large-sized uredia without necrosis. The variations in each class are indicated by the use of - (less than average for the class) and + (more than average for the class). When variable reactions were observed IT ranges are listed from lowest to highest

${ }^{\mathrm{b}} P t$ race designation as per accepted nomenclature. The $P s t$ races designations as per accepted nomenclature. $P g t$ race designation as per accepted nomenclature

${ }^{c}$ Assessment of disease produced from controlled pathogen inoculations conducted in the MSU-PGC

d Assessment of disease produced from exposure to native pathogen populations in the field at Creston, MT

e Assessment of disease produced from controlled inoculations conducted in the greenhouse at Pullman, WA

${ }^{\mathrm{f}}$ Assessment of disease produced from controlled pathogen inoculations conducted in the contained laboratory at St Paul, MN; Pgt race Ug99 is the newly identified race and current focus of stem rust resistance breeding, therefore, the five-letter race identifications of Ug99 (TTKSK) and its derivatives are highlighted in gray
} 
ments at the adult plant stage to local $P t$ and Pst populations. The predominant $P t$ races were SBDGD and BBBDD and the Pst races were PST-127 and PST-139 (Wang and Chen, unpublished data). MNR220 showed an immune response to leaf rust and a resistance response to stripe rust, whereas Alpowa was susceptible to both diseases in the field (Table 1).

Characteristics of the defense responses of MNR220 at the seedling and the adult plant stages

The response of MNR220 to $P t$ race PBJL was dosage dependent and developmentally specific. At the seedling stage, both Alpowa and MNR220 showed necrosis at infection sites 3-4 dpi, but by 6 dpi the rust on Alpowa was sporulating, whereas MNR220 had only necrosis flecks (Fig. 2a). The seedling low infection type normally can last until 18 dpi (Fig. 2a). The delayed sporulation observed on MNR220 at seedling stage became insignificant after $18 \mathrm{dpi}$ when the infection types on MNR220 were the same as on Alpowa (Fig. 2a). However, when tested at the adult plant stage, infection and disease development on Alpowa mirrored seedling stage inoculations, whereas MNR220 showed only HR-like flecks from 6 dpi until leaf senescence (around $35 \mathrm{dpi}$, data not shown). Figure $2 \mathrm{~b}$ only shows the infection types up to $24 \mathrm{dpi}$.

In order to evaluate the response spectra to another fungal pathogen, MNR220 was inoculated with a mixture of Bgt (unknown race identification) collected from the Plant Growth Center at Montana State University. The mutant's
Fig. 2 Leaf rust disease development at three time points postinoculation with $P$. triticina race PBJL. a Infection types at the seedling stage. b Infection types at the adult plant stage

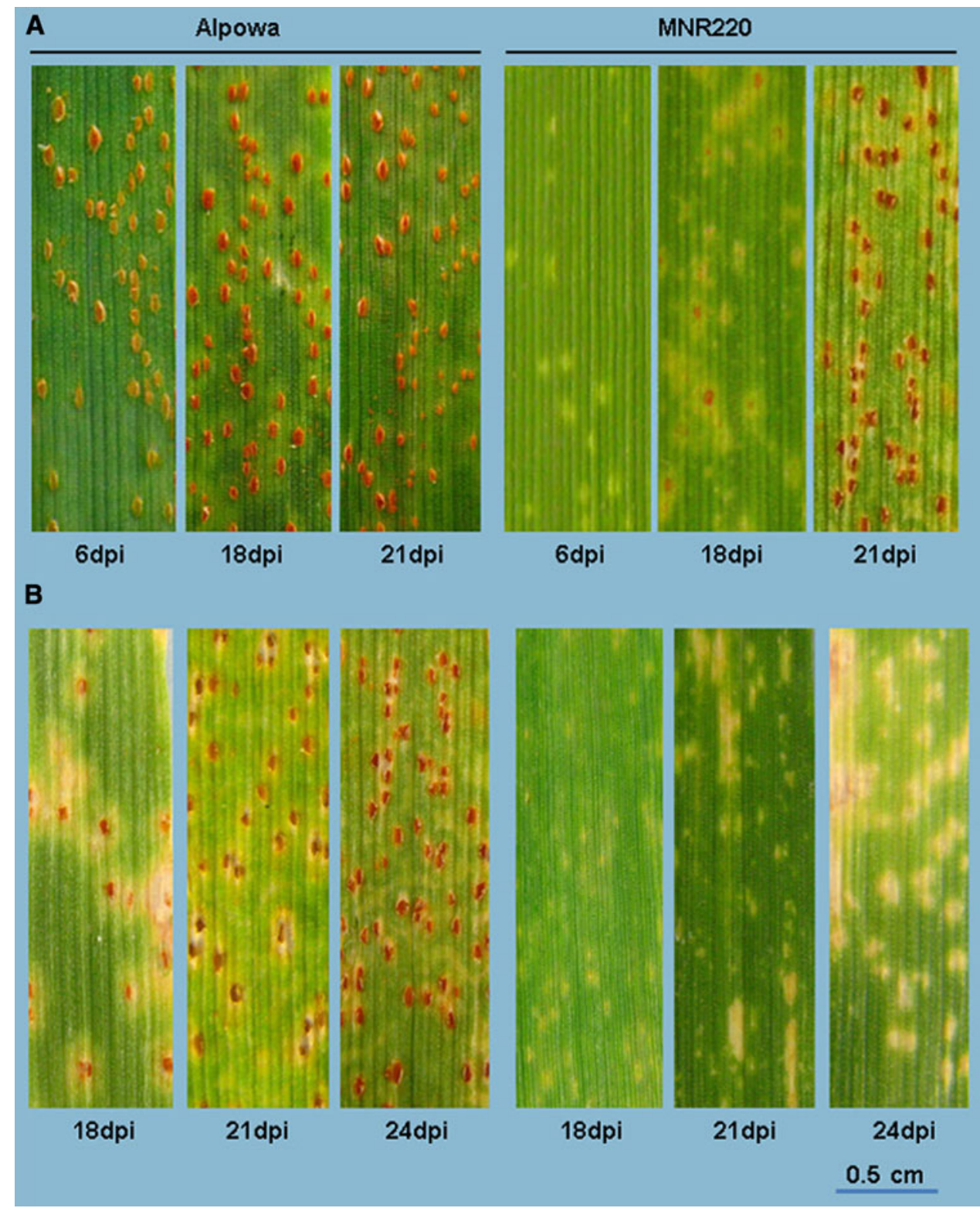




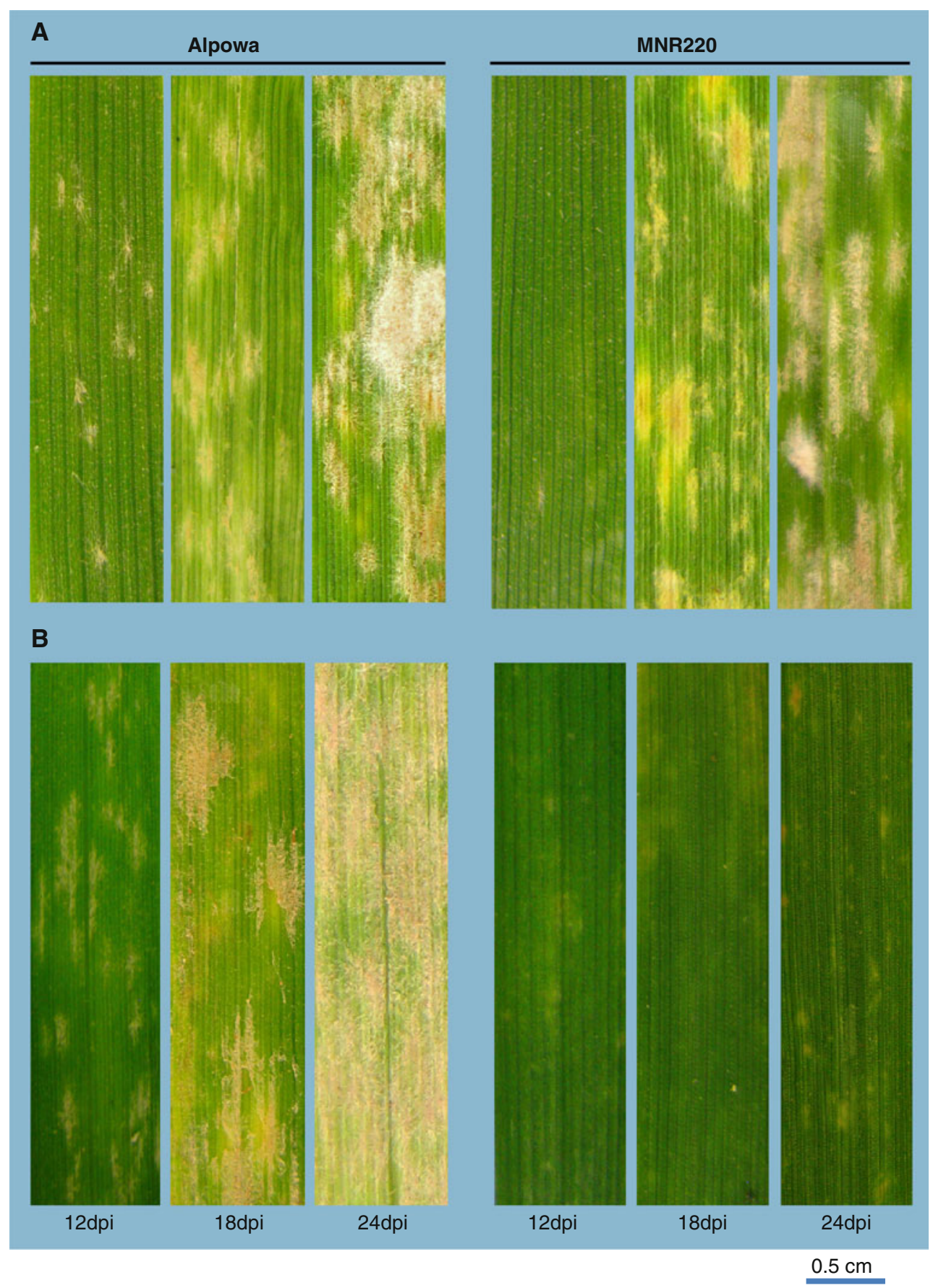

Fig. 3 Powdery mildew disease development at three time points post-inoculation with B. graminis. a Infection types at the seedling stage. b. Infection types at the adult plant stage

response to powdery mildew was similar to that observed in response to leaf rust, with the characteristics of delayed disease symptoms at the seedling stage. The first post-inoculation time point when the wild type and MNR220 had visually observable difference to Bgt was 12 dpi when Alpowa showed patches of mycelium and conidia on the leaf surface and MNR220 had almost none (Fig. 3a); and the difference between wild type and the mutant was insignificant at 18 dpi. When inoculated with Bgt post-tiller devel- opment, MNR220 remained highly resistant until leaf senescence around $35 \mathrm{dpi}$, whereas Alpowa was fully susceptible (Fig. 3b).

\section{Morphology of MNR220}

After crossing 220-1 with Alpowa and followed by four generations of backcrossing with Alpowa and selfing, lines that carried the resistance conferred by MNR220 had few 
phenotypic differences from wild-type Alpowa. Under greenhouse conditions, the advanced MNR220 lines had similar tiller numbers, maturity date, and seed morphologies as Alpowa, but leaf senescence starting from the lower leaves 5 6 days before heading was earlier than Alpowa (Fig. 4). Additionally, traits such as plant height, spike morphology, and tip sterility segregated in backcrossed and selfed MNR220 progenies. Importantly, none of the morphological differences between the mutant and the wildtype co-segregated with resistance to PBJL.

Genetic analysis and mapping of disease resistance locus in MNR220

Crosses of $\mathrm{M}_{6}$ MNR220 with spring wheat cultivars Alpowa (as male parent) and Chinese Spring (CItr 14108) (as female parent) were used for genetic analysis. Ten $\mathrm{F}_{1}$ individuals each from the two crosses were tested as resistant to $P t$-PBJL, indicating dominance of the mutant allele. Interestingly, $\mathrm{F}_{1}$ individuals from the cross of Chinese Spring/ MNR220 were more resistant (IT 1) to PBJL than those of cross MNR220/Alpowa (IT 2-2). In addition, there were observable differences in the speed of leaf rust disease development between lines heterozygous and homozygous for the MNR220 allele. On MNR220 homozygous lines, small- to medium-sized uredinia developed at the infection sites by 16 dpi whereas on MNR220 heterozygous lines, uredinia developed as early as $8 \mathrm{dpi}$. The segregation ratios of resistance to PBJL in the $\mathrm{F}_{2}$ populations derived from the two crosses were consistent with expected segregation at a single dominant locus (Table 2). In addition, eight selected homozygous $\mathrm{F}_{2: 3}$ lines of MNR220/Alpowa (four resistant and four susceptible lines to $P t$ race $P B J L$ ) and $98 \mathrm{~F}_{2: 3}$ lines of Chinese Spring/MNR220 were also tested with $P t$ race PBJL, $P g t$ race TLMKC and a mixture of unknown races of $B g t$ (20 seedlings/line/race). Resistance to Pt, Pgt, and Bgt was perfectly co-segregated among the $8+98$ lines.

Genetic mapping of the MNR220 locus was based on the genomic DNAs from 95 individual $\mathrm{F}_{2}$ plants and the genotypes of the corresponding $\mathrm{F}_{2: 3}$ lines from a cross between Chinese Spring/MNR220. Randomly selected 358 SSR markers that cover 21 chromosomes of hexaploid wheat were used to initially screen polymorphisms between Chinese spring and MNR220. Among them, 109 markers were polymorphic between the two parents. Only two markers (Xbarc55 and Xwmc154) were polymorphic between the parents and the resistant and susceptible bulks. These markers are located on the short arm of chromosome 2B. Since then, 62 more SSR markers located on 2BS were screened, two more (Xgwm429 and Xbarc183) revealed the same polymorphic patterns between the parents and the bulks. These four polymorphic markers were tested in the entire population. The MNR220 locus was placed between Xgwm429 and Xbarc183. Based on the physical location of these two SSR markers, the MNR220 locus was narrowed down to a single deletion bin 2BS-0.53-0.75 on chromosome 2B (Somyong et al. 2011). Therefore, 12 wheat EST-STS markers from that interval were used to screen polymorphism between the parents and the bulks. XBE497494-STS (developed from wheat EST BE497494) was the only

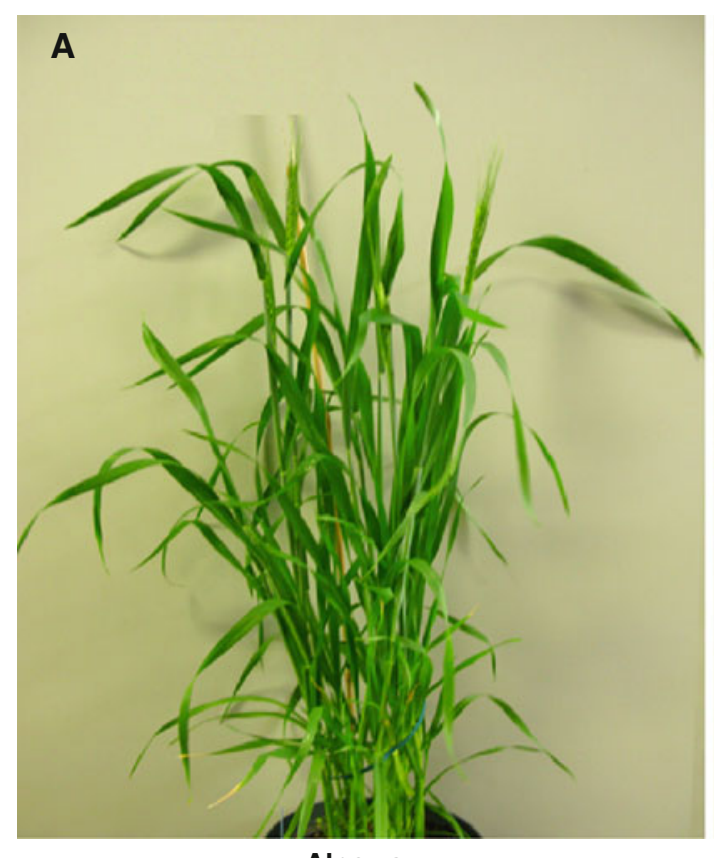

Alpowa

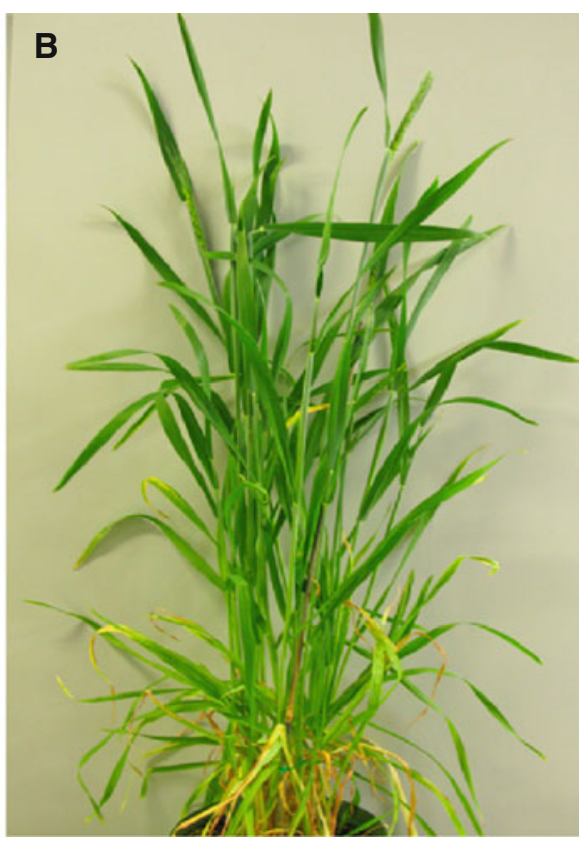

MNR220

Fig. 4 Adult plant phenotype. a. Alpowa and b. MNR220 
Table 2 Segregation analysis of seedling leaf rust resistance in the MNR220/Alpowa $\mathrm{BC}_{1} \mathrm{~F}_{2}$ and Chinese Spring/MNR220 $\mathrm{F}_{2}$ populations

\begin{tabular}{llllll}
\hline Cross & \multicolumn{2}{l}{$\mathrm{F}_{2}$ individuals $^{\mathrm{a}}$} & $\begin{array}{l}\text { Expected } \\
\text { ratio }\end{array}$ & $\chi^{2 \mathrm{c}}$ & $P^{\mathrm{d}}$ \\
\cline { 2 - 5 } & Resistant & Susceptible & & \\
\hline MNR220/Alpowa & 210 & 71 & $3: 1$ & 0.01 & 0.9 \\
$\begin{array}{l}\text { Chinese Spring/ } \\
\text { MNR220 }\end{array}$ & 100 & 36 & $3: 1$ & 0.16 & 0.69 \\
\hline
\end{tabular}

${ }^{\text {a Number of individuals in } \mathrm{F}_{2} \text { populations assessed as resistant or }}$ susceptible to $P t$ race. PBJL based on 0 (immune)-4 (susceptible) infection type scale

${ }^{\mathrm{b}}$ Expected Mendelian single gene segregation ratio (R:S)

c Calculated Chi-square $\left(\chi^{2}\right)$

d The likelihood that the observed segregation ratio does not fit a 3:1 ratio. There was no segregation for leaf rust resistance observed in $>100$ seedlings of each selfed Alpowa, or Chinese Spring

marker that revealed polymorphism between the two parents and the bulks. Among the 5 polymorphic markers, 3 (Xbarc55, Xwmc154, and Xgwm429) were co-dominant, and 2 (Xbarc183 and XBE497494-STS) were dominant. A linkage map including all five polymorphic markers and the MNR220 locus was constructed and shown in Fig. 5. The $M N R 220$ locus is flanked by the SSR marker Xbarc183 and the STS marker XBE497494-STS. Marker Xbarc183 is $12.6 \mathrm{cM}$ proximal to the $M N R 220$ locus, and XBE497494STS is $9.3 \mathrm{cM}$ distal to the locus.

Expression profiling of pathogenesis-related $(P R)$ genes

In order to understand how the mutation in MNR220 altered the defense response regulation, we assessed the expression profiles of seven $P R$ genes in near isogenic lines (NILs) with either homozygous MNR220 or mnr220 alleles derived from one selected heterozygous $\mathrm{M}_{7}$ plant after eight generations of selfing and PBJL testing (Fig. 1, for details, see "Materials and methods"). The seven $P R$ genes were chosen based on their involvement in defense responses to fungal pathogens in wheat (Desmond et al. 2008) and the primers were designed based on wheat sequence and are able to amplify all three orthologous copies of each $P R$ gene in hexaploid wheat genome (data not shown). The transcript abundances were measured using quantitative reverse transcription-polymerase chain reaction (RTqPCR). To estimate the basal expression levels of the $P R$ genes in the NILs, we measured the gene transcript abundances in leaf tissues collected immediately after PBJL inoculation ( 0 time point) in both two leaf stage seedlings and adult plant flag leaves. The RT-qPCR results revealed similar patterns of transcript abundances for four of the seven selected $P R$ genes at the seedling (Fig. 6a) and the adult plant (Fig. 6b) stages. These four $P R$ genes ( $P R 1$, $P R 2, P R 3$, and $P R 9$ ) showed higher levels of transcript

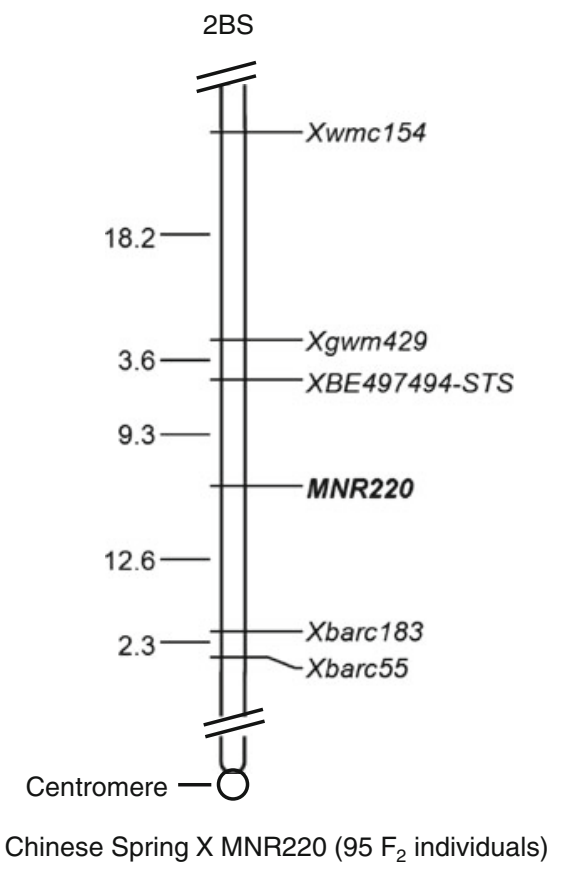

Genetic map of MNR220

Fig. 5 Genetic map of the MNR220 locus constructed with the DNAs from 95 individual $\mathrm{F}_{2}$ plants and the genotypes from the corresponding $\mathrm{F}_{2: 3}$ lines from a cross between Chinese Spring and MNR220

abundances in resistant MNR220 than in susceptible $m n r 220$ NIL at both the seedling and adult plant stages. The differences between the MNR220 and mnr220 were more significant at the seedling stage than those at the adult plant stage for $P R 1, P R 2$ and $P R 3$ and less significant for $P R 9$ at both stages (Fig. 6a, b). Transcript abundances of $P R 5$ in adult plants were approximately fivefold higher in the MNR220 NIL compared to mnr220. Similar transcript abundances of PR4 were detected between the NILs at adult stage, but were approximately twofold higher in the MNR220 NIL than mnr220 at the seedling stage. In contrast, transcript abundances of $P R 10$ were higher in the $M N R 220$ NIL at the seedling stage, but lower in $m n r 220$ at the adult plant stage (Fig. 6a, b).

In order to analyze pathogen-induced changes in the seven $P R$ gene expression levels during disease development, we measured transcript abundances at five time points post pathogen inoculation. The measurements were taken from leaves collected from bulks of five plants at 0 , $0.5,1,1.5$ and $5.5 \mathrm{dpi}$ and averaged over two independent biological replications. Figure 7 shows the differences between MNR220 and mnr220 at the levels of transcript abundances of the seven $P R$ genes. The basal expressions of all seven $P R$ genes in the MNR220 NIL were a little higher than those in $m n r 220$ which was normalized as 100 and indicated by a horizontal dash line. The transcript abundances of all seven $P R$ genes peaked at 0.5 dpi 

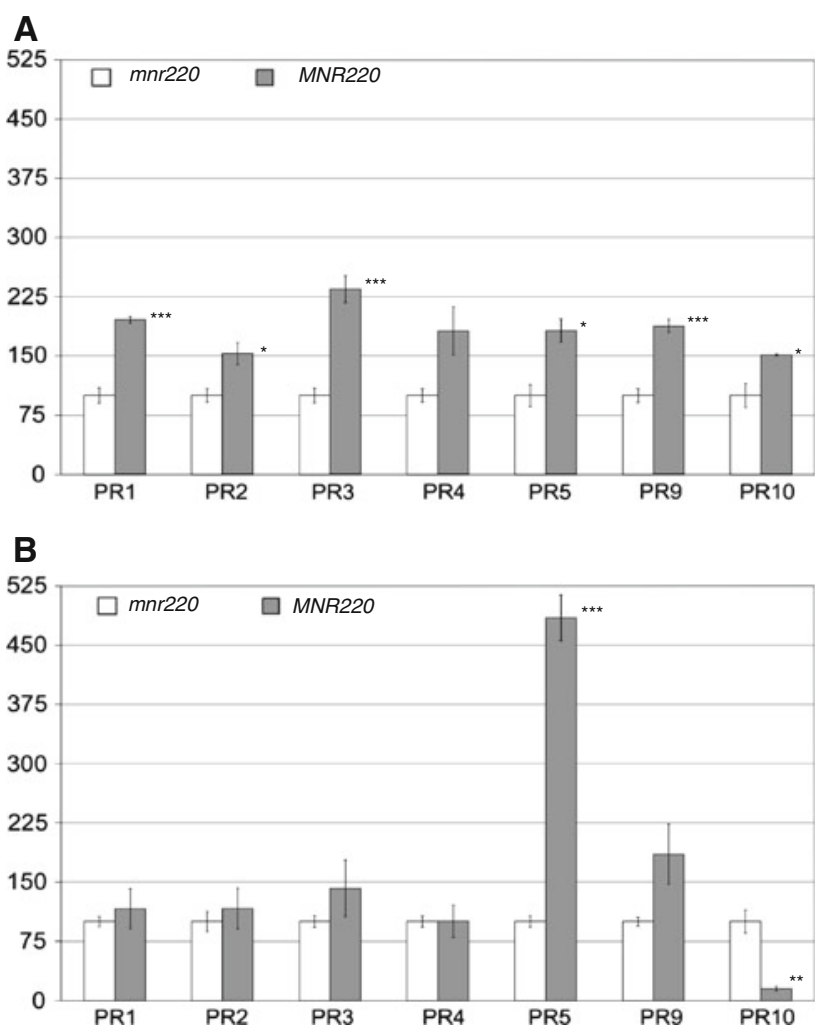

Fig. $6 P R$ gene transcript abundance profiles. a RT-qPCR $P R$ transcript abundance at seedling stage at 0 time point of PBJL inoculation. b. RT-qPCR $P R$ gene transcript abundance at adult plant stage in the absence of pathogens. Transcript abundance, $y$-axis, given as percent abundance normalized to mnr220. Error bars represent standard deviation between biological replicates. Mean percent transcript abundance calculated using the $\Delta \Delta C_{\mathrm{t}}$ method between biological replicates \pm standard deviation. Unpaired two-tailed students $t$ test between mean of mnr220 and MNR220 and statistical significance indicated as $* 0.025 \leq p<0.05, * * 0.01<p<0.025, * * * p \leq 0.01$

(Fig. 7), suggesting the largest difference between the NILs was at 0.5 dpi. The differences between the NILs were insignificant at $1.0 \mathrm{dpi}$ (Fig. 7), suggesting the transcript abundances of the $P R$ genes in the mnr220 NIL have increased to similar levels as in the MNR220 NIL, but were $12 \mathrm{~h}$ delayed (Fig. 7). At $1.5 \mathrm{dpi}$, the relative expressions of $P R$ genes were all below the dash line, indicating the transcript abundances of the $P R$ genes in the MNR220 NIL were lower than those in the mnr220 NIL. At $5.5 \mathrm{dpi}$, the relative expressions of $P R$ genes were all close to the dash line, indicating the transcript abundances of the $P R$ genes in the MNR220 NIL were similar to those in the mnr220 NIL. This preliminary gene expression analysis indicates that these $P R$ genes in the MNR220 NIL were activated and responded to the pathogen earlier after infection than in the mnr220 NIL.

\section{Discussion}

A new seedling slow-rusting allele created in MNR220

Rust resistance genes have two modes of action determined by pathogen interaction and are either race specific or race non-specific. Characteristics of race non-specific resistance include the "slow-rusting" resistance features, longer latent period, and decreased uredinial size and number (Dyck 1987; German and Kolmer 1992; Singh and Gupta 1992; Singh et al. 1998). There are known slow-rusting stem ( $S r 2)$, leaf ( $L r 34, L r 46$, and $L r 67)$, and stripe (Yrl8) rust resistance genes. $\mathrm{Sr} 2$ is associated with a dark pigmentation trait, called pseudo-black chaff (PBC), expression of which is modified by both biotic and abiotic stresses (Kota et al. 2006). Durable resistance has been achieved in cultivars with $S r 2$ and is enhanced by minor genes (Dyck 1987). The resistance conferred by Lr34 has been well studied (Dyck et al. 1994; Singh and Rajaram 1992; Singh and Gupta 1992). The Lr34 gene encodes a putative ABC transporter and confers non-hypersensitive resistance to multiple fungal pathogens in wheat (Krattinger et al. 2009). Lr34 is
Fig. $7 P R$ gene transcript abundance profiles during leaf rust disease development. RT-qPCR $P R$ gene transcript abundance in response to PBJL at seedling stage. Transcript abundances in MNR220 were normalized to $m n r 220$ at corresponding time point. Error bars represent standard deviation between biological replicates

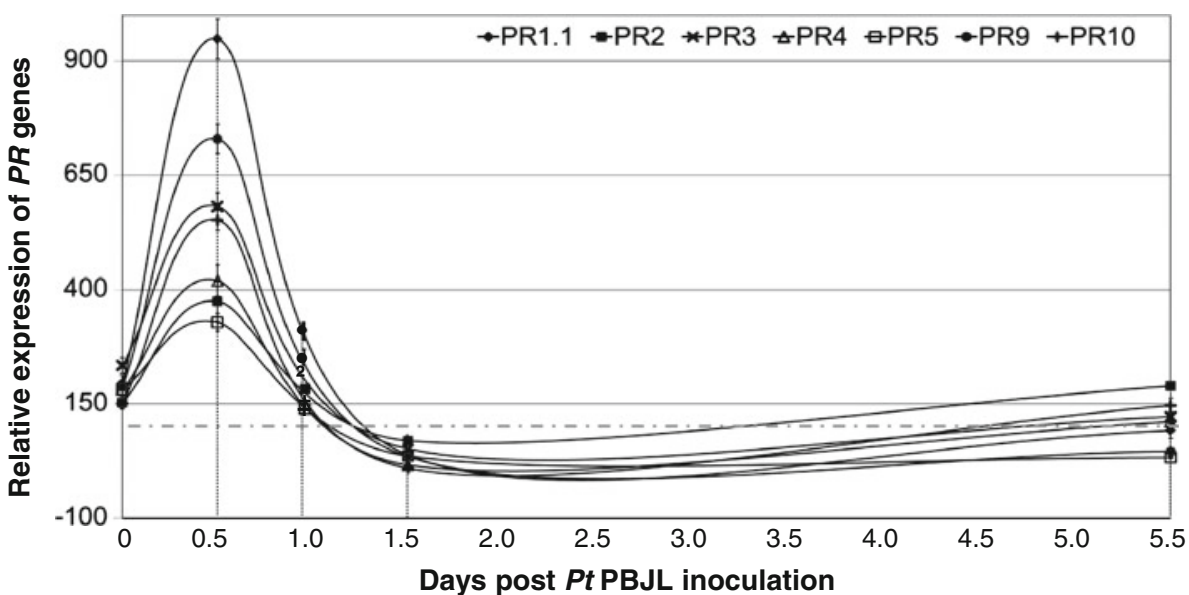


characterized as an adult plant resistance gene because of the compatible interaction with the pathogen at the seedling stage although seedling resistance of $\operatorname{Lr} 34$ can be induced by low temperature (Pretorius et al. 1993).

Alpowa is a soft, white, semi-dwarf, spring wheat cultivar released by Washington AES/USDA-ARS in 1994. Since its release, Alpowa was reported to carry the rust resistance genes $\operatorname{Lr} 3 a, Y r 39$, and YrAlp but carries neither Lr34 nor Sr2. Lr3a does not confer resistance to the primary race $P t$ PBJL utilized in this study. The stripe rust resistance gene $\operatorname{Yr} 39$ confers high-temperature adult plant (HTAP) and $Y r A l p$ confers all-stage resistance to a few old US Pst races (Lin and Chen 2007).

The resistance conferred by MNR220 has the characteristics of a slow-rusting resistance gene to leaf rust race PBJL at the seedling stage with a 10-day latency period increase, but complete resistance at the adult plant stage to leaf and stripe rusts and powdery mildew. MNR220 showed an early HR-like response to leaf rust and powdery mildew at the seedling and the adult plant stages, but the seedling resistance was compromised after $18 \mathrm{dpi}$, whereas the adult plant resistance remained effective. These developmental stage-dependent responses were further described in the gene expression profiles of seven $P R$ genes at both the seedling and adult plant stages. The profiles revealed elevated expression of four $P R$ genes in the absence of infection and a $12 \mathrm{~h}$ earlier increase of all seven $P R$ genes after pathogen attack in MNR220 compared to mnr220. These results suggest that the mutation changes the regulation of the defense response leading to higher basal defense to certain fungal pathogens, but this basal defense response was eventually overcome by the pathogens at the seedling stage. Two $P R$ genes showed different expression profiles between the NILs of MNR220 and mnr220 at the adult plant stage. Basal transcript abundance of PR5 was fivefold higher in MNR220 at the adult plant stage. The PR5 gene family encodes proteins with homology to thaumatin, osmotin and NP24 which are known to rapidly accumulate to high levels in response to biotic or abiotic stress (Velazhahan et al. 1999). This group of proteins has antifungal activity either by causing fungal membrane lysis at high concentrations or cell membrane leakage at low concentrations (Velazhahan et al. 1999). Transgenic tobacco, potato, and rice over-expressing PR5 showed higher resistance to several fungal pathogens (Velazhahan et al. 1999). It is unclear whether the elevated level of PR5 alone was sufficient to make the adult plant resistance complete.

Disease resistance in MNR220 is associated with changes in negative regulation

Genetic and gene expression analysis revealed that MNR220 activates expression of five $P R$ genes that were suppressed in MNR220 in the absence of pathogens. Suppression of $P R$ gene expression is a negative regulation, which is thought to be an important mechanism to avoid inappropriate defense responses that are metabolically expensive, and may result in yield penalties to the plants (Brown 2002).

There are three possible mutational events that can change the negative regulation. The first possibility is a loss-of-function event where the mutation disrupts a wildtype negative regulator of resistance. A number of negative regulators of cell death have been identified by the occurrence of spontaneous necrotic lesions in mutants with inactivated regulators (Dangl and Jones 2001). These "lesion mimic" mutants often display increased resistance to pathogens but their mode of action remains unclear as in the acdl, lsdl and svnl mutations described in Arabidopsis thaliana (Lorrain et al. 2003; for review see Dangl and Jones 2001; McDowell and Dangl 2003). The mutant MNR220 does not show lesion mimic, but starts leaf senescence earlier than wild-type Alpowa. However, this process is different from the flag leaf tip necrosis associated with the Lr34 gene (Krattinger et al. 2009), the mutant leaves turn yellow similar to the aging process starting from the oldest leaves, while the flag leaves still maintain green. Alternatively, the mutation could disrupt a pathogenrequired host factor. These host factors are negative regulators of disease resistance that are necessary for pathogen invasion. The Mlo gene family is an example of a host factor required by $B g t$ for invasion. Mlo genes encode heptahelical plasma membrane-localized proteins of unknown function (Büschges et al. 1997; Panstruga 2005).

The second possibility is a gain-of-function event where the mutation creates a new functional resistance allele. This new resistance allele could activate the $R$-gene mediated defense response pathways. Several resistance gainof-function mutations have been reported including the semidominant mutation ssi4 (Shirano et al. 2002) and the dominant mutation sncl in Arabidopsis (Zhang et al. 2003). The gain-of-function mutations in sncl and ssit are the result of a constitutive activated $\mathrm{R}$ protein induction of defense response.

The third possibility is a loss-of-function event where the mutation disrupts an $R$-gene suppressor. There are several reports of suppressors of rust resistance in wheat (Assefa and Fehrmann 2000; Kerber and Green 1980; Knott 2000; Nelson et al. 1997) where the suppressor suppresses positive regulators of the defense response pathway. These suppressors have been shown to repress the effects of $R$ genes located on the A or B genomes of bread wheat (Kerber and Green 1980).

It is unclear, without molecular cloning, whether the $M N R 220$ allele is a gain-of-function or a loss-of-function allele. With multiple highly conserved orthologous copies 
of each $P R$ gene in hexaploid wheat, it is unknown which orthologs of each $P R$ gene transcript abundance was altered by the mutation. However, compared to the mnr220 NIL, the enhanced transcript levels of the $P R$ genes in the mutant suggest the disease resistance in MNR220 is associated with changes in negative regulation in the defense pathways.

Resistance to multiple fungal pathogens is likely associated with a single locus in MNR220

The mutation rate in the EMS-mutagenized population used in this study was estimated to be 1 in $11.5 \mathrm{~kb}$ of DNA (Feiz et al. 2009) which suggests that many mutations occurred in each individual. Several traits mostly from different mutations including plant height, spike morphology, and tip sterility, segregated in the selfed progeny of MNR220 but none co-segregated with disease resistance. Resistance to leaf rust, stem rust and powdery mildew co-segregated in total $106 \mathrm{~F}_{2: 3}$ lines derived from two crosses. It is therefore probable that resistance to multiple fungal pathogens in MNR220 is conferred by a single locus. Single gene multipathogen resistance is consistent with evidence suggesting limited sets of defense-related molecules in each host are used to defend against highly diverse pathogens (Dangl and Jones 2001), although more genes are likely to be involved in either enhancing or reducing the levels of defense response evidenced by our observation that $F_{1}$ individuals from the cross of Chinese Spring/MNR220 were more resistant to PBJL than those of cross of MNR220/Alpowa. This also supports the findings that even evolutionarily diverse pathogens target similar host defense immunity machinery (Mukhtar et al. 2011). In addition to our report here, one other mutant plant conferring resistance to multiple rust pathogens has been reported in wheat (Boyd et al. 2006). Only large scale progeny testing and molecular cloning of the gene(s) will reveal the true basis of the MNR220 mutation. Molecular analysis of the disease resistance locus in MNR220 may lead to a better understanding of the regulation of defense response networks in wheat.

Acknowledgments We thank Dr. Luther Talbert and the Spring Wheat Breeding Lab at Montana State University for help with the field test at NWARC in Creston, MT and SSR primers used for genetic mapping, Dr. James Kolmer of the Cereal Disease Laboratory, St. Paul, MN 55108, USA for race identification of leaf rust collected in Creston, Montana 2010 and Dr. Robert McIntosh of the Plant Breeding Institute, Cobbitty, NSW2570, Australia for editing the manuscript. This research was supported by the Montana Wheat and Barley Committee and the BREAD program (grant IOS-0965429).

Open Access This article is distributed under the terms of the Creative Commons Attribution License which permits any use, distribution, and reproduction in any medium, provided the original author(s) and the source are credited.

\section{References}

Arumuganathan K, Earle ED (1991) Nuclear DNA content of some important plant species. Plant Mol Bio Rep 9:208-218

Assefa S, Fehrmann H (2000) Resistance to wheat leaf rust in Aegilops tauschii Coss. and inheritance of resistance in hexaploid wheat. Genet Res Crop Evol 47:135-140

Board WWAO (2010) In Economic Research Service, Foreign Agricultural Service, USDA, ed

Bouarab K, Melton R, Peart J, Baulcombe D, Osbourn A (2002) A saponin-detoxifying enzyme mediates suppression of plant defences. Nature 418:889-892

Boyd LA, Smith PH, Hart N (2006) Mutants in wheat showing multipathogen resistance to biotrophic fungal pathogens. Plant Pathol $55: 475-484$

Brown JKM (2002) Yield penalties of disease resistance in crops. Curr Opin Plant Biol 5:339-344

Büschges R, Hollricher K, Panstruga R, Simons G, Wolter M, Frijters A, van Daelen R, van der Lee T, Diergaarde P, Groenendijk J, Töpsch S, Vos P, Salamini F, Schulze-Lefert P (1997) The barley Mlo gene: a novel control element of plant pathogen resistance. Cell 88:695-705

Colilla FJ, Rocher A, Mendez E (1990) $\gamma$-Purothionins: amino acid sequence of two polypeptides of a new family of thionins from wheat endosperm. Fed Eur Biochem Soc Lett 270:191-194

Dangl JL, Jones JDG (2001) Plant pathogens and integrated defence responses to infection. Nature 411:826-833

Desmond OJ, Manners JM, Schenk PM, Maclean DJ, Kazan K (2008) Gene expression analysis of the wheat response to infection by Fusarium pseudograminearum. Physiol Mol Plant Pathol 73:4047

Dvořák J, Terlizzi PD, Zhang HB, Resta P (1993) The evolution of polyploid wheats: identification of the A genome donor species. Genome 36:21-31

Dyck PL (1987) The association of a gene for leaf rust resistance with the chromosome 7D suppressor of stem rust resistance in common wheat. Genome 29:467-469

Dyck PL, Kerber ER, Aung T (1994) An interchromosomal reciprocal translocation in wheat involving leaf rust resistance gene $\operatorname{Lr} 34$. Genome 37:556-559

Feiz L, Beecher BS, Martin JM, Giroux MJ (2009) In planta mutagenesis determines the functional regions of the wheat puroindoline proteins. Genetics 183:853-860

Flor HH (1956) The complementary genic systems in flax and flax rust. In: Iacobellis NS, Collmer A, Hutcheson SW, Mansfield JW, Morris CE, Murillo J, Schaad NW, Stead DE, Surico G, Ullrich $M$ (eds) Advances in Genetics. Kluwer Academic Academic Presss, Dordrecht, pp 29-54

German SE, Kolmer JA (1992) Effect of gene Lr34 in the enhancement of resistance to leaf rust of wheat. Theor Appl Genet 84:97-105

Glazebrook J (2005) Contrasting mechanisms of defense against biotrophic and necrotrophic pathogens. Annu Rev Phytopathol 43:205-227

Jin Y, Singh RP, Ward RW, Wanyera R, Kinyua M, Njau P, Fetch T, Pretorius ZA, Yahyaoui A (2007) Characterization of seedling infection types and adult plant infection responses of monogenic $S r$ gene lines to race TTKS of Puccinia graminis f. sp tritici. Plant Dis 91:1096-1099

Jin Y, Szabo LJ, Pretorius ZA, Singh RP, Ward R, Fetch T (2008) Detection of virulence to resistance gene $S r 24$ within race TTKS of Puccinia graminis f. sp. tritici. Plant Dis 92:923-926

Jin Y, Szabo LJ, Rouse MN, Fetch T, Pretorius ZA, Wanyera R, Njau P (2009) Detection of virulence to resistance gene Sr36 within the TTKS race lineage of Puccinia graminis f. sp. tritici. Plant Dis 93:367-370 
Kerber ER, Green GJ (1980) Suppression of stem rust resistance in the hexaploid wheat cv. Canthatch by chromosome 7DL. Can J Bot 58:1347-1350

Knott DR (2000) Inheritance of resistance to stem rust in medea durum wheat and the role of suppressors. Crop Sci 40:98-102

Kota R, Spielmeyer W, McIntosh RA, Lagudah ES (2006) Fine genetic mapping fails to dissociate durable stem rust resistance gene $\mathrm{Sr} 2$ from pseudo-black chaff in common wheat (Triticum aestivum L.). Theor Appl Genet 112:492-499

Krattinger SG, Lagudah ES, Spielmeyer W, Singh RP, Huerta-Espino J, McFadden H, Bossolini E, Selter LL, Keller B (2009) A putative $\mathrm{ABC}$ transporter confers durable resistance to multiple fungal pathogens in wheat. Science 323:1360-1363

Lin F, Chen XM (2007) Genetics and molecular mapping of genes for race-specific all-stage resistance and non-race-specific high-temperature adult-plant resistance to stripe rust in spring wheat cultivar Alpowa. Theor Appl Genet 114:1277-1287

Lincoln S, Daly M, Lander E (1992) Constructing genetic maps with Mapmaker/EXP3.0 Whitehead Institute Technical Report, 3rd edn. Whitehead Institute, Cambridge

Line RF, Qayoum A (1992) Virulence, aggressiveness, evolution, and distribution of races of Puccinia striiformis (the cause of stripe rust of wheat) in North America. USDA-ARS. Tech Bull 1788:44

Liu RH, Meng JL (2003) MapDraw: a Microsoft Excel macro for drawing genetic linkage maps based on given genetic linkage data. Hereditas (Beijing) 25:317-321

Lorrain S, Vailleau F, Balagué C, Roby D (2003) Lesion mimic mutants: keys for deciphering cell death and defense pathways in plants. Trends Plant Sci 8:263-271

McDowell JM, Dangl JL (2003) Signal transduction in the plant immune response. Trends Biochem Sci 25:79-82

McFadden ES, Sears ER (1964) The origin of Triticum spelta and its free-threshing hexaploid relatives. J Hered 37:107-116

McIntosh RA, Wellings CR, Park RF (1995) Wheat rusts: an atlas of rust genes. CSIRO Publication, East Melbourne, pp 28-55

Michelmore RW, Paran I, Kesseli VR (1991) Identification of markers closely linked to disease-resistance genes by bulked segregant analysis: a rapid method to detect markers in specific genomic regions by using segregating populations. Proc Natl Acad Sci USA 88:9828-9832

Mukhtar MS, Carvunis AR, Dreze M, Epple P, Steinbrenner J, Moore J, Tasan M, Galli M, Hao T, Nishimura MT, Pevzner SJ, Donovan SE, Ghamsari L, Santhanam B, Romero V, Poulin MM, Gebreab F, Gutierrez BJ, Tam S, Monachello D, Boxem M, Harbort CJ, McDonald N, Gai L, Chen H, He Y, Consortium EUE, Vandenhaute J, Roth FP, Hill DE, Ecker JR, Vidal M, Beynon J, Braun P, Dangl JL (2011) Independently evolved virulence effectors converge onto hubs in a pant immune system network. Science 333:596-601
Nelson JC, Singh RP, Autrique JE, Sorrells ME (1997) Mapping genes conferring and suppressing leaf rust resistance in wheat. Crop Sci 37:1928-1935

Panstruga R (2005) Serpentine plant MLO proteins as entry portals for powdery mildew fungi. Biochem Soc Trans 33:389-392

Pretorius ZA, Kloppers FJ, Drijepondt SC (1993) Effects of inoculum density and temperature on three components of leaf rust resistance controlled by Lr34 in wheat. Euphytica 74:91-96

Pretorius ZA, Singh RP, Wagoire WW, Payne TS (2000) Detection of virulence to wheat stem rust resistance gene $S r 31$ in Puccinia graminis. f. sp. tritici in Uganda. Plant Dis 84:203

Rubiales D, Niks RE (1995) Characterization of Lr34, a major gene conferring nonhypersensitive resistance to wheat leaf rust. Plant Dis 79:1208-1212

Sarkar P, Stebbins GL (1956) Morphological evidence concerning the origin of the B genome in wheat. Am J Bot 43:297-304

Shirano Y, Kachroo P, Shah J, Klessig DF (2002) A gain-of-function mutation in an Arabidopsis toll interleukin1 receptor-nucleotide binding site-leucine-rich repeat type $R$ gene triggers defense responses and results in enhanced disease resistance. Plant Cell 14:3149-3162

Singh RP, Gupta AK (1992) Expression of wheat leaf rust resistance gene Lr34 in seedlings and adult plants. Plant Dis 76:489-491

Singh RP, Rajaram S (1992) Genetics of adult-plant resistance of leaf rust in 'Frontana' and three CIMMYT wheats. Genome 35:24-31

Singh RP, Mujeeb Kazi A, Huerta-Espino J (1998) Lr46: a gene conferring slow-rusting resistance to leaf rust in wheat. Phytopathology 88:890-894

Somyong S, Munkvold JD, Tanaka J, Benscher D, Sorrells ME (2011) Comparative genetic analysis of wheat seed dormancy QTL with rice and Brachypodium identifies candidate genes for $\mathrm{ABA}$ perception and calcium signaling. Funct Integr Genomics 11(3):479-490

Stakman EC, Stewart DM, Loegering WQ (1962) Identification of physiologic races of Puccinia graminis var. tritici. In: Agricultural Research Service, Agriculture. USDA, Washington DC

Stokstad E (2007) Deadly wheat fungus threatens world's breadbaskets. Science 315:1786-1787

Velazhahan R, Datta SK, Muthukrishnan S (1999) The PR-5 family: thaumatin-like proteins. In: Iacobellis NS, Collmer A, Hutcheson SW, Mansfield JW, Morris CE, Murillo J, Schaad NW, Stead DE, Surico G, Ullrich M (eds) Pathogenesis-related proteins in plants. Kluwer Academic CRC Presss, Dordrecht, p 303

Wanyera R, Kinyua MG, Jin Y, Singh R (2006) The spread of Puccinia graminis f. sp. tritici with virulence on $\mathrm{Sr} 31$ in Eastern Africa. Plant Dis 90:113

Zhang Y, Goritschnig S, Dong X, Li X (2003) A gain-of-function mutation in a plant disease resistance gene leads to constitutive activation of downstream signal transduction pathways in suppressor of npr1-1, constitutive 1. Plant Cell 15:2636-2646 